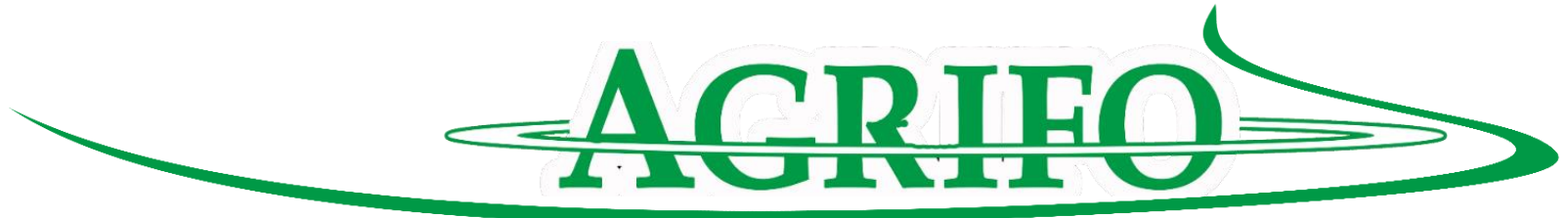

\title{
ANALISIS FAKTOR-FAKTOR YANG MEMPENGARUHI PERMINTAAN KONSUMEN TERHADAP TELUR AYAM RAS DI DESA TAMBON BAROH KECAMATAN DEWANTARA KABUPATEN ACEH UTARA
}

\section{Murdani $^{1}$}

Email Author: murdanix@gmail.com

\section{ABSTRACT}

The purpose of this study is to analyze the factors that affect consumer demand for eggs in Tambon Baroh Village, Sub-district of Dewantara, North Aceh District The research method used is quantitative method with multiple linear regression analysis model. The results of this study indicate that simultaneously the price of eggs (X1), tempe price (X2), income (X3), the number of dependents (X4) and appetite (D) have a significant effect on the demand of eggs in Tambon Baroh Village, Dewantara Subdistrict North Aceh district because the sig value of 0.000 is smaller than the alpha value of 0.05 . Partially only the price of eggs $(0.000<0,05)$, tempe price $(0,010<0,05)$ and the dependent amount $(0,015<0,05)$ have a significant effect on demand of chicken egg because the value of sig $t$ is smaller than alpha 0.05 . While the income $(0,413>0,05)$ and the taste $(0,399>0,05)$ had no significant effect on the demand of chicken egg in Tambon Baroh Village, Dewantara District, North Aceh Regency because the sig t value is greater than alpha 0,05 .

Keywords: Demand, Consumer, Egg

\section{PENDAHULUAN}

\subsection{Latar Belakang}

Telur merupakan salah satu bahan pangan yang banyak dikonsumsi oleh masyarakat di Indonesia. Telur merupakan salah satu sumber protein hewani yang mengandung nutrisi yang baik bagi kehidupan manusia. Konsumsi telur lebih tinggi daripada konsumsi hasil ternak lain, karena lebih mudah diperoleh, harganya relatif lebih murah dan terjangkau bagi masyarakat yang mempunyai daya beli rendah. Salah satu jenis telur yang paling banyak dikonsumsi oleh masyarakat Indonesia adalah telur ayam ras. Telur ayam ras tergolong telur yang mempunyai ukuran lebih besar daripada telur ayam kampung dan telur itik dengan berat 55-65 gram/butir. Berikut adalah tabel konsumsi beberapa jenis telur per kapita di Indonesia tahun 2013-2014.

Tabel 1. Konsumsi Beberapa Jenis Telur Per Kapita

\begin{tabular}{|c|c|c|c|}
\hline No & Komoditas & $\begin{array}{l}\text { Tahun 2013-2014 (Kg } \\
\text { Per Kapita) }\end{array}$ & Pertumbuhan (\%) \\
\hline 1 & Telur Ayam Ras & $6.15-6.31$ & 3 \\
\hline 2 & Telur Ayam Kampung & $2.61-2.61$ & 0 \\
\hline 3 & Telur Itik & $1.83-1.51$ & -17 \\
\hline 4 & Telur Puyuh & $3.39-3.75$ & 11 \\
\hline 5 & Telur Asin & $1.04-0.94$ & -10 \\
\hline
\end{tabular}

Sumber: Pusat Data dan Informasi Pertanian, 2015

\footnotetext{
${ }^{1}$ Staff Pengajar Program Studi Agribisnis Fakultas Pertanian Universitas Malikussaleh
} 
Berdasarkan Tabel 1 konsumsi masyarakat terhadap telur ayam ras mengalami pertumbuhan sebesar 3 persen. Hal ini menunjukkan bahwa konsumsi masyarakat terhadap telur ayam ras per kapita yang terus meningkat. Kebutuhan masyarakat akan telur ayam ras yang terus meningkat mencerminkan selera masyarakat yang baik terhadap telur ayam ras itu sendiri. Kesadaran masyarakat akan pentingnya nilai gizi menjadi salah satu pemicu meningkatnya kebutuhan akan telur ayam ras. Tingkat konsumsi telur ayam akan terus meningkat karena faktor karakteristik produk unggas yang harganya terjangkau oleh masyarakat luas, berkualitas gizi baik, disukai oleh konsumen segala umur, tersedia dalam jumlah yang cukup dan dapat diolah menjadi berbagai jenis makanan serta penyebarannya dapat menjangkau seluruh wilayah di Indonesia.
Aceh merupakan salah satu Provinsi yang mengkonsumsi telur ayam ras di Indonesia. Jumlah permintaan masyarakat terhadap telur ayam ras terus meningkat setiap tahunnya. Konsumsi telur ayam ras di Aceh sendiri mencapai $25.566 .247 \mathrm{~kg} /$ tahun atau setara 409.1 juta butir atau 0.24 butir/kapita per hari berdasarkan data 2011 (Nurbaiti, 2013). Telur ayam ras sebagai salah satu jenis telur yang paling banyak dikonsumsi oleh masyarakat bukanlah barang asing yang sulit untuk kita jumpai. Telur ayam ras terdapat hampir di setiap sudut Kota maupun di Desa di berbagai tempat di Indonesia khususnya di Aceh. Salah satunya adalah di Desa Tambon Baroh Kecamatan Dewantara Kabupaten Aceh Utara. Berikut diperlihatkan tabel jumlah permintaan telur ayam ras di Desa Tambon Baroh dalam kurun waktu 4 bulan terakhir.

Tabel 2. Distribusi Jumlah Permintaan Telur Ayam Ras di Desa Tambon Baroh 20162017 Dalam Kurun Waktu 4 Bulan Terakhir

\begin{tabular}{lll}
\hline No & Bulan & Jumlah Permintaan Telur (Butir) \\
\hline 1 & Oktober & 11.760 butir \\
2 & November & 12.460 butir \\
3 & Desember & 13.440 butir \\
4 & Januari & 12.240 butir \\
\hline Jumlah & & 49.440 butir \\
\hline
\end{tabular}

Sumber: Data Primer Diolah, 2017

Berdasarkan Tabel 2 dapat dilihat bahwa pada bulan Oktober jumlah permintaan telur ayam ras mencapai 11.760 butir dan meningkat menjadi 12.460 butir pada bulan November, bahkan pada bulan Desember jumlah permintaan konsumen terhadap telur ayam menyentuh angka 13.440 butir. Akan tetapi pada bulan Januari permintaan konsumen terhadap telur ayam ras menurun menjadi 12.240 butir, jumlah ini bahkan lebih sedikit daripada jumlah permintaan telur ayam ras di Bulan November, fluktuasi pemintaan terhadap telur ayam ras secara jelas terjadi dari periode bulan Oktober hingga Januari walaupun cenderung meningkat, untuk itu perlu dilakukan penelitian terhadap fluktuasi permintaan konsumen terhadap telur ayam ras. Berdasarkan fenomena tersebut maka perlu dilakukan analisis tentang faktorfaktor yang mempengaruhi permintaan konsumen terhadap telur ayam ras di Desa Tambon Baroh Kecamatan Dewantara Kabupaten Aceh Utara. 


\subsection{Rumusan Masalah}

Berdasarkan latar belakang di atas maka masalah yang dapat dirumuskan adalah faktor-faktor apa saja yang mempengaruhi permintaan konsumen terhadap telur ayam ras di Desa Tambon Baroh Kecamatan Dewantara Kabupaten Aceh Utara?

\subsection{Tujuan Penelitian}

Berdasarkan masalah tersebut maka tujuan dari penelitian ini adalah untuk menganalisis faktor-faktor apa saja yang mempengaruhi permintaan konsumen terhadap telur ayam ras di Desa Tambon Baroh Kecamatan Dewantara Kabupaten Aceh Utara?

\section{METODE PENELITIAN \\ 2.1. Lokasi, Objek dan Ruang Lingkup Penelitian}

Penelitian ini dilakukan di Desa Tambon Baroh Kecamatan Dewantara Kabupaten Aceh Utara. Objek penelitian ini adalah konsumen yang telah membeli dan mengkonsumsi telur ayam ras minimal 2 (dua) kali dalam seminggu. Ruang lingkup penelitian hanya menganalisa faktor-faktor yang mempengaruhi permintaan konsumen terhadap telur ayam ras di Desa Tambon Baroh Kecamatan Dewantara Kabupaten Aceh Utara.

\subsection{Jenis dan Sumber Data}

a. Data hasil pengamatan langsung ke lapangan (observasi), wawancara dan penyebaran kuisioner.

b. Data dari referensi-referensi terkait, seperti buku-buku, jurnal penelitian dan data dari instansi terkait.

\subsection{Populasi dan Sampel}

Populasi dalam penelitian adalah seluruh konsumen yang telah melakukan pembelian dan mengkonsumsi telur ayam ras di Desa Tambon Baroh Kecamatan Dewantara Kabupaten Aceh Utara. Teknik pengambilan sampel yang dilakukan menggunakan metode Accidental Sampling yaitu semua pembeli yang dijumpai di lokasi penelitian dan melakukan pembelian terhadap telur-telur ayam ras serta sesuai karakteristiknya, yaitu sudah berkeluarga serta telah melakukan pembelian dan mengkonsumsi telur ayam ras minimal 2 (dua) kali dalam seminggu dengan pertimbangan bahwa responden tersebut telah memiliki kesiapan untuk diwawancarai atau telah dapat dijadikan sumber data.

Penetapan jumlah sampel mengacu kepada pendapat (Hair,1998) bahwa penentuan jumlah sampel yang tidak diketahui ukuran populasinya seperti dalam penelitian ini dianjurkan di atas 30 sampel.

Jumlah sampel dalam peneltian ini ditetapkan sebanyak 35 responden, dimana dari 35 responden tersebut tidak dibatasi terkait penggunaan telur ayam ras, baik penggunaannya untuk konsumsi harian ataupun untuk membuat kue dan lain-lain.

\subsection{Metode Analisis Data}

Metode analisis data yang digunakan dalam penelitian ini adalah metode kuantitif dengan model analisisnya adalah regresi linear berganda, yaitu untuk menganalisis hubungan antara variabel bebas yaitu harga telur ayam ras $\left(\mathrm{X}_{1}\right)$, harga tempe $\left(\mathrm{X}_{2}\right)$, pendapatan konsumen $\left(\mathrm{X}_{3}\right)$, jumlah tanggungan $\left(\mathrm{X}_{4}\right)$ dan selera $(\mathrm{D})$ dengan variabel terikat yaitu jumlah permintaan telur ayam ras (Y). Dan juga untuk 
mengetahui sejauh mana besarnya pengaruh variabel bebas terhadap variabel terikat (Nazir, 1999).

Persamaan matematis regresi linear berganda untuk permintaan telur ayam ras sebagai berikut:

$Y=a+b_{1} X_{1}+b_{2} X_{2}+b_{3} X_{3}+b_{4} X_{4}+$ b5 $\mathbf{D}+\mathbf{e}$

Keterangan:

$\mathrm{Y}=$ jumlah permintaan telur ayam ras

a = bilangan konstanta

$\mathrm{b}=$ koefisien regresi

$\mathrm{X}_{1} \quad=$ harga telur ayam ras (Rp/butir)

$\mathrm{X}_{2} \quad=$ harga tempe (Rp/potong)

$\mathrm{X}_{3} \quad=$ pendapatan konsumen (Rp/bulan)

$\mathrm{X}_{4}=$ jumlah tanggungan (jiwa)

$\mathrm{D} \quad=$ Selera

$\mathrm{D}=1$, jika konsumen suka telur ayam ras

$\mathrm{D}=0$, jika konsumen tidak suka telur ayam ras

\section{HASIL DAN PEMBAHASAN}

3.1. Gambaran Umum Wilayah Penelitian

Wilayah penelitian ini yaitu di Desa Tambon Baroh Kecamatan Dewantara Kabupaten Aceh Utara. Desa Tambon Baroh terletak di pinggir jalan raya Medan-Banda Aceh dan terdiri dari empat dusun, yaitu (Dusun I Sejahtera,
Dusun II Sentosa, Dusun III Perdamaian dan Dusun IV Bahagia) dengan batas wilayah sebagai berikut:

- Sebelah Utara berbatasan dengan Keude Krueng Geukueh dan Selat Malaka

- Sebelah Selatan berbatasan dengan Desa Tambon Tunong

- Sebelah Timur berbatasan dengan Kecamatan Muara Satu, Pemko Lhokseumawe

- Sebelah Barat berbatasan dengan Desa Uteun Geulinggang dan Desa Paloh Lada

Sumber: Kantor Keuchik Desa Tambon Baroh, 2017

\subsection{Faktor-Faktor yang Mempengaruhi Permintaan Konsumen Terhadap Telur Ayam Ras}

Ayam ras yang dikaji dalam penelitian ini yaitu harga telur ayam ras $\left(X_{1}\right)$, harga tempe $\left(X_{2}\right)$, pendapatan $\left(X_{3}\right)$, jumlah tanggungan $\left(\mathrm{X}_{4}\right)$, selera (D). Masing -masing variabel bebas (independen) tersebut dapat dilihat tingkat pengaruhnya tehadap variabel terikat (dependen) yaitu jumlah permintan telur ayam ras. Untuk lebih jelasnya mengenai tingkat pengaruh variabel bebas yang digunakan dalam penelitian ini terhadap permintaan telur ayam ras dapat dilihat pada tabel berikut: Tabel 8. Hasil Analisis Regresi

\begin{tabular}{lll}
\hline Variabel & Koefisien & Sig \\
\hline (Constant) & 208,365 & 0,000 \\
Harga Telur Ayam Ras $\left(\mathrm{X}_{1}\right)$ & $-0,159$ & 0,000 \\
Harga Tempe $\left(\mathrm{X}_{2}\right)$ & 0,013 & 0,010 \\
Pendapatan $\left(\mathrm{X}_{3}\right)$ & $-9,745$ & 0,413 \\
Jumlah Tanggungan $\left(\mathrm{X}_{4}\right)$ & 2,369 & 0,015 \\
Selera (Dummy) & 3,009 & 0,399 \\
\hline $\mathrm{R}^{2}=0,686$ & $\mathrm{~F}_{\text {hitung }}=12,644 \quad \mathrm{~F}_{\text {sig }}=0,000$ \\
$\mathrm{R}=0,828$ & \\
\hline
\end{tabular}

Sumber: Data Primer Diolah, 2017 
Dari hasil analisis yang terdapat pada Tabel 8 maka dapat ditulis rumus regresi fungsi permintaa telur ayam ras yaitu:

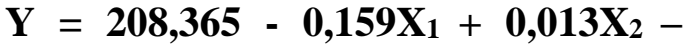 $9.745 X_{3}+2,369 X_{4}+3,009 D$}

Berdasarkan Tabel 7 hasil uji koefisien determinasi $\left(\mathrm{R}^{2}\right)$ menunjukkan bahwa koefisien korelasi (R) sebesar 0,828 atau $82,8 \%$ ini berarti bahwa secara bersamaan variabel bebas mempunyai hubungan yang erat dengan variabel terikat. Sedangkan nilai koefisien determinasi $\left(\mathrm{R}^{2}\right)$ adalah 0,686 ini berarti bahwa $68,6 \%$ kemampuan variasi himpunan variabel bebas yang digunakan dalam model ini dapat menjelaskan variasi permintaan telur ayam ras. Sedangkan sisanya $31,4 \%$ dijelaskan oleh variasi variabel lain di luar model.

Hasil uji $\mathrm{F}$ didapat nilai sebesar 12,644 dan nilai Sig F sebesar 0,000 lebih kecil dari alpha 0,05, berarti hipotesis statistik dari penelitian ini dapat diterima dan disimpulkan bahwa harga telur ayam ras, harga tempe, pendapatan, jumlah tanggungan dan selera secara serempak berpengaruh signifikan terhadap permintaan telur ayam ras di Desa Tambon Baroh Kecamatan Dewantara Kabupaten Aceh Utara.

\subsubsection{Harga Telur Ayam Ras}

Harga menetukan seberapa besar jumlah barang yang akan diminta, sehingga harga merupakan salah satu faktor penentu banyak atau sedikitnya barang yang dibeli oleh konsumen. Dari hasil analisis dapat dilihat bahwa nilai koefisien harga telur ayam ras adalah 0,159 (negatif) dan berpengaruh signifikan terhadap permintaan telur ayam ras karena nilai sig t lebih kecil dari alpha $(0,000<0,05)$, Aartinya jika harga telur ayam ras mengalami kenaikan harga yaitu sebesar Rp. 1, 00 maka akan menurunkan permintaan telur ayam ras sebesar 0,15 butir.

Hasil analisis yang menyebutkan bahwa signifikannya harga suatu barang terhadap permintaan barang itu sendiri juga sesuai dengan penelitian terdahulu yang dilakukan di Kota Lhokseumawe dengan judul analisis faktor-faktor yang mempengaruhi permintaan tempe. Dalam penelian ini harga tempe juga berpengaruh signifikan terhadap permintaan tempe di Kota Lhokseumawe (Sasika'ati, 2013).

\subsubsection{Harga Tempe}

Hasil penelitian ini menunjukkan bahwa variabel harga tempe berpengaruh secara signifikan terhadap permintaan telur ayam ras, hal ini dapat dilihat dari nilai koefisien sebesar 0,013 (positif) dan nilai sig t lebih kecil dari alpha $(0,010<0,05)$. Sehingga dapat disimpulkan bahwa jika harga tempe naik sebesar Rp. 1,00 maka permintaan telur ayam ras akan meningkat sebesar 0,01 butir.

Hasil analisis ini juga sesuai dengan penelitian terdahulu yang dilakukan di Desa Jombang Kecamatan Ciputat Kabupaten Tanggerang Selatan dengan judul analisis faktor-faktor yang mempengaruhi permintaan tempe. Dalam penelitian ini harga barang lain yaitu harga daging berpengaruh signifikan terhadap permintaan tempe di Desa tersebut (Ulfa, 2011).

\subsubsection{Pendapatan Konsumen}

Menurut teori apabila pendapatan konsumen semakin tinggi maka akan diikuti daya beli konsumen yang kuat dan mampu membeli barang dan jasa dalam jumlah yang lebih besar, demikian sebaliknya. Hasil dari penelitian ini 
menunjukkan bahwa nilai koefisien pendapatan adalah -9,745 (negatif) dan nilai sig t 0,413, lebih besar dari alpha $(0,05)$. Artinya pendapatan mempunyai pengaruh tidak signifikan terhadap permintaan telur ayam ras dikarenakan nilai sig t yang lebih besar dari alpha $(0,05)$. Hal ini terjadi karena jumlah pendapatan konsumen dalam penelitian yang cenderung tinggi, sehingga konsumen akan selalu mampu untuk memenuhi kebutuhan akan telur ayam ras, baik itu untuk kebutuhan konsumsi harian ataupun untuk keperluan lainnya seperti membuat kue.

\subsubsection{Jumlah Tanggungan}

Hasil analisis menunjukkan nilai koefisien sebesar 2,369 (positif) bahwa variabel jumlah tanggungan bertanda positif dan berpengaruh signifikan terhadap permintaan telur ayam ras di Desa Tambon Baroh Kecamatan Dewantara Kabupaten Aceh Utara. Hal ini dapat dilihat dari nilai sig $\mathrm{t}$ yang lebih kecil dari alpha $(0,015<0,05)$. Artinya jika jumlah tanggungan bertambah 1 orang maka permintaan telur ayam ras akan mengalami kenaikan sebesar 2,3 butir.

Hasil analisis ini sesuai dengan peneltian terdahulu yang dilakukan di Kota Banda Aceh dengan judul analisis faktor-faktor yang mempengaruhi permintaan konsumen rumah tangga terhadap gula pasir. Dalam penelitian ini jumlah tanggungan juga berpengaruh signifikan terhadap permintaan gula pasir di Kota Banda Aceh (Miftia, 2007).

\subsubsection{Selera}

Selera berpengaruh terhadap jumlah permintaan konsumen terhadap suatu barang. Semakin besar selera konsumen terhadap suatu barang maka akan semakin banyak jumlah barang yang akan dibeli. Hasil analisis menunjukkan nilai koefisien selera sebesar 3,009 (positif) dan sig t 0,399, lebih besar dari alpha 0,05. Selera mempunyai pengaruh yang tidak signifikan terhadap permintaan telur ayam ras, atau dengan kata lain suka atau tidaknya konsumen terhadap telur ayam ras tidak berpengaruh terhadap volume permintaan telur ayam ras.

Hal ini mungkin juga dikarenakan letak Desa Tambon Baroh yang bersebelahan dengan Desa Keude Krueng Geukueh yang memiliki pasar tradisional terlengkap serta menyediakan berbagai jenis bahan pangan lainnya sehingga lebih banyak varian bahan pangan yang dapat dipilih sebagai pengganti telur ayam ras bagi konsumen yang tidak menyukai telur ayam ras.

\section{PENUTUP \\ 4.1. Kesimpulan}

Jumlah permintaan telur ayam ras di Desa Tambon Baroh Kecamatan Dewantara Kabupaten Aceh Utara dipengaruhi oleh faktor harga telur ayam ras $\left(\mathrm{X}_{1}\right)$, harga tempe $\left(\mathrm{X}_{2}\right)$, pendapatan $\left(\mathrm{X}_{3}\right)$, jumlah tanggungan $\left(\mathrm{X}_{4}\right)$ dan selera (D). Secara simultan (serempak) penelitian ini menunjukkan bahwa faktor harga telur ayam ras $\left(\mathrm{X}_{1}\right)$, harga tempe $\left(\mathrm{X}_{2}\right)$, pendapatan $\left(\mathrm{X}_{3}\right)$, jumlah tanggungan $\left(\mathrm{X}_{4}\right)$ dan selera (D) berpengaruh signifikan terhadap permintaan telur ayam ras di Desa Tambon Baroh Kecamatan Dewantara Kabupaten Aceh Utara.

Secara parsial (satu-satu) hanya variabel harga telur ayam ras $(0,000<$ $0,05)$, harga tempe $(0,010<0,05)$ dan jumlah tanggungan $(0,015<0,05)$ yang berpengaruh signifikan terhadap permintaan telur ayam ras. Sedangkan pendapatan $(0,413>0,05)$ dan selera $(0,399>0,05)$ berpengaruh tidak signifikan terhadap permintaan telur ayam ras di Desa Tambon Baroh 
Kecamatan Dewantara Kabupaten Aceh Utara.

\subsection{Saran}

Pemerintah diharapkan untuk terus memantau harga jual telur ayam ras, hal ini dikarenakan telur ayam ras merupakan salah satu bahan makanan pokok yang digemari oleh seluruh lapisan masyarakat yang disamping itu juga merupakan bahan makanan pokok yang sangat rentan mengalami fluktuasi harga.

Penulis juga berharap bagi masyarakat untuk lebih bijak dalam memilih bahan makanan untuk dikonsumsi, bahwa dalam membeli suatu bahan makanan pokok yang dilihat bukan hanya soal kuantitas akan tetapi juga soal kualitas.

\section{DAFTAR PUSTAKA}

Hair, J.F. Jr. Anderson, R.E. Tathan R.L and W.C. 1998. Multivariant Data Analisis. USA. Pretince Hall Inc.

Miftia, Afrida Cut. 2007. Analisis Faktor-faktor yang Memepengaruhi
Konsumen Rumah Tangga terhadap Gula Pasir di Kota Banda Aceh. Skripsi. Fakultas Pertanian. Universitas Syiah Kuala.

Nazir, M. 1999. Metode Penelitian. Ghalia Indonesia. Jakarta.

Nurbaiti. 2013. Faktor-faktor yang Mempengaruhi Permintaan Telur Ayam di Kota Banda Aceh. Skripsi. Universitas Syiah Kuala. Banda Aceh.

Sasika'ati. 2013. Analisis Faktor-faktor yang Mempengaruhi Perminaan Tempe di Kota Lhokseumawe (Pasar Inpres dan Pasar Pusong). Skripsi. Program Studi Agribisnis. Fakultas Pertanian. Universitas Malikussaleh.

Ulfa, A. 2011. Analisis Faktor-faktor yang Mempengaruhi Permintaan Tempe di Kota Jombang Kecamatan Ciputan Kota Tanggerang Selatan Provinsi Banten. Skipsi. Fakultas Sains dan Teknologi. Universitas Islam Negeri Syarif Hidayatullah. Jakarta. 